\title{
"KESINAMBUNGAN ANTARA PEMERINTAH DAN MASYARAKAT DALAM KERJASAMA SISTER CITY DI KOTA BANJARMASIN DAN SAMARINDA"
}

\section{FIRDANETA JANNATUNNAIM RAMADHANA - Kelas B}

Selama ini yang menjadi masalah terkait tentang pengelolaan lingkungan lahan basah yaitu adanya saling tumpang tindih antara satu kepentingan dengan kepentingan lainnya. Kelemahan dalam tata kelola lingkungan lahan basah juga dapat diihat dari kurangnya tenaga ahli, dan kurangnya pemahaman dari para pemangku kepentingan, selain itu juga transformasi global seperti perubahan iklim global, globalisasi budaya dan kebijakan pembangunan dapat berpengaruh terhadap keberlanjutan lahan basah di Indonesia. Salah satunya di kota Banjarmasin dapat dilihat dari tata kelola yang buruk dan tidak sistematis ini diakibatkan karena tidak adanya sinergi yang positif antara pemerintah dan masyarakat. Sehingga melihat dari fenomena tersebut pemerintah melakukan kerjasama bilateral yaitu model kerjasama sister city (mitra kota). Model kerjasama sister city pada Kota Banjarmasin ini menekankan untuk masyarakat berperan aktif dalam mengelola lingkungan lahan basah secara terpadu guna untuk mengurangi dan menghadapi permasalahan sumber daya alam baik dari segi kualitas maupun kuantitasnya.

Lain halnya di Kota Samarinda, permasalahan yang sedang dialami yaitu terkait dengan adanya banjir. Kondisi banjir di Kota Samarinda sangat meresahkan aktivitas masyarakat, padahal berbagai upaya pemerintah sudah dijalankan seperti pemeliharaan drainase kota, perbaikan sungai yang melintasi kota, serta aturan pengendalian banjir masih belum optimal. Sehingga pemerintah menerapkan konsep kerjasama sister city yang diharapkan dapat menjalin kerjasama antara satu kota dengan kota yang lain dalam mengatasi permasalahan banjir. Dalam konsep kerjasama sister city yang ada di Kota Samarinda menerapkan dua model yang berbeda yaitu kerjasama sister city top-down dan kerjasama sister city bottom-up. Padahal kedua model tersebut sama-sama menitikberatkan masyarakat untuk berperan aktif dalam penanganan masalah banjir yang ada. Konsep model kolaborasi ini terletak pada upaya pemerintah dan masyarakatnya. Dalam hal ini, pemerintah sebagai pengawas dan pemberi kebijakan kepada masyarakat, sedangkan masyarakat sebagai alat untuk menjalankan perintah tersebut. 


\section{REFERENCES}

Al Syahrin, M. N., Mahyuni, A., Sompa, A. T., Jamaluddin, A. I., Budhi, S., Rachman, D., \& Alunaza, H. (2019). BOTTOM-UP MODEL ANALYSIS OF COMMUNITY INVOLVEMENT IN THE SISTER CITY COOPERATION FOR FLOOD MITIGATION IN EAST KALIMANTAN.

Al Syahrin, M. N., Mahyuni, M., Apriansyah, A., Sompa, A. T., Jamaluddin, J., Asmu'i, A., ... \& Alunaza, H. (2020). Bottom-Up Model Analysis of Community Involvement in the Sister City Cooperation for Flood Mitigation in East Kalimantan. Revista UNISCI/UNISCI Journal, (53), 143-156.

Al Syahrin, M. N., Mahyuni, T. T., Riyadi, H., \& Rahmah, A. (2021). MODEL RANCANGAN KERJA SAMA SISTER CITY KOTA KEMBAR BANJARMASIN DALAM TATA KELOLA LINGKUNGAN LAHAN BASAH (WETLAND GOVERNANCE). In PROSIDING SEMINAR NASIONAL LINGKUNGAN LAHAN BASAH (Vol. 6, No. 3).

Al Syahrin, M. Najeri, Apriansyah Mahyuni, Andi Tenri Sompa, Asmu'I. Jamaluddin, Setia Budhi, Dzul Rachman, and Hardi Alunaza. "BOTTOM-UP MODEL ANALYSIS OF COMMUNITY INVOLVEMENT IN THE SISTER CITY COOPERATION FOR FLOOD MITIGATION IN EAST KALIMANTAN." (2019).

Al Syahrin, M. Najeri, M. Mahyuni, A. Apriansyah, Andi Tenri Sompa, J. Jamaluddin, A. Asmu'i, Setia Budhi, Dzul Rachman, and Hardi Alunaza. "Bottom-Up Model Analysis of Community Involvement in the Sister City Cooperation for Flood Mitigation in East Kalimantan." Revista UNISCI/UNISCI Journal 53 (2020): 143-156.

Al Syahrin, M. Najeri, Terry Tabitha Mahyuni, Husama Riyadi, and Anisa Rahmah. "MODEL RANCANGAN KERJA SAMA SISTER CITY KOTA KEMBAR BANJARMASIN DALAM TATA KELOLA LINGKUNGAN LAHAN BASAH (WETLAND GOVERNANCE)." In PROSIDING SEMINAR NASIONAL LINGKUNGAN LAHAN BASAH, vol. 6, no. 3. 2021.

Mahyuni, M., \& Syahrin, M. N. (2021). Sister City Cooperation Model In Wetland Environmental Governance: Case Study In Banjarmasin, South of Kalimantan. International Journal of Politic, Public Policy and Environmental Issues, 1(02), 115-125.

Mahyuni, Mahyuni, and Muhammad Najeri Syahrin. "Sister City Cooperation Model In Wetland Environmental Governance: Case Study In Banjarmasin, South of Kalimantan." International Journal of Politic, Public Policy and Environmental Issues 1, no. 02 (2021): 115-125.

Syahrin, M. N. A., Rukmana, G. M., Rachman, D., Harakan, A., \& Tadjine, F. (2019). Sister city bottom up collaborative model plan as a major flooding mitigation in Samarinda.

Syahrin, Muhammad Najeri Al, Gilang Mukti Rukmana, Dzul Rachman, Ahmad Harakan, and Farida Tadjine. "Sister city bottom up collaborative model plan as a major flooding mitigation in Samarinda." (2019). 